\title{
Economic Potential of Internationally-Oriented Patenting Activity in Russia
}

\author{
Irina Ervits
}

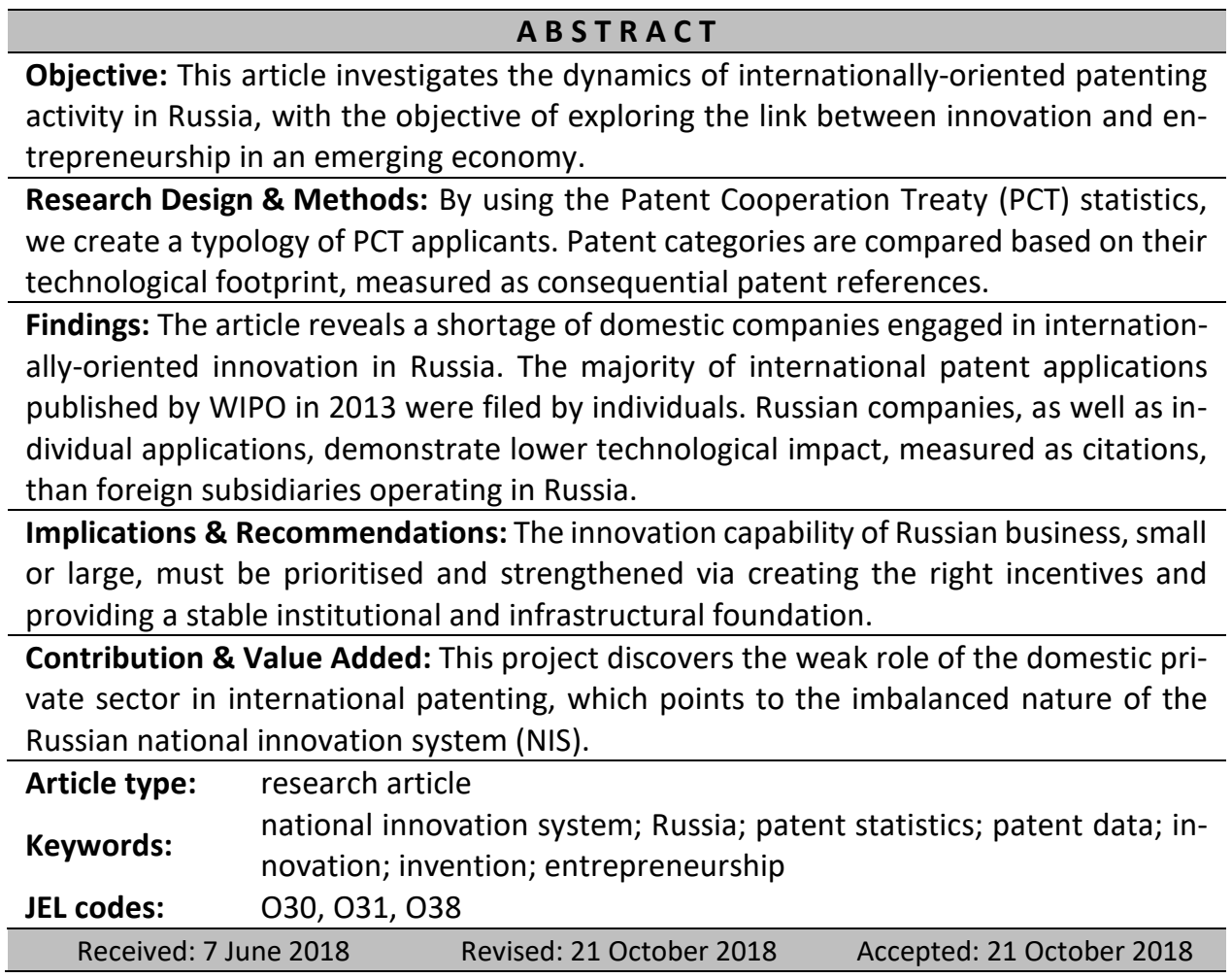

Suggested citation:

Ervits, I. (2019). Economic Potential of Internationally-Oriented Patenting Activity in Russia. Entrepreneurial Business and Economics Review, 7(1), 75-94. https://doi.org/10.15678/EBER.2019.070105 


\section{INTRODUCTION}

This project operates under the assumption that patenting is an important indicator of inventive activity, which in turn is an integral part of the innovation process ${ }^{1}$. We look at the nature of so-called 'international' patent applications from Russia filed through the Patent Cooperation Treaty (PCT) and published by the World Intellectual Property Organization (WIPO) in 2013. By using this database we pursue three objectives. First, we create a typology of patent applicants involved in internationally-oriented invention activity in Russia. As applied to emerging economies ${ }^{2}$ such as Russia, where admittedly the institutional protection of intellectual property rights is lacking (Kouznetzov \& Jones, 2009, p. 90), which then inhibits the commercial use of invention, we should expect that patent applications seeking international approval will involve a genuine intention to internationalise or diffuse these inventions abroad. The relationship between the two strategies in pursuit of growth-innovation and internationalisation-is an underdeveloped field of research (Hagen, Denicolai, \& Zucchella, 2014), and patent activity in the form of PCT applications represents a combination of the two strategies. In this respect we look into the nature of actors engaged in internationally-oriented innovation in Russia.

The second reason to understand the nature of patenting activity in Russia is to gain insights into the Russian national system of innovation (NIS) ${ }^{3}$ and its external spillovers. The systematic approach to analysing the process of innovation at the national level or NIS underscores the dynamism of interactions between public and private institutions (Freeman, 1995; Nelson, 1993). The major elements of NIS include private businesses and universities, as well as government-financed research institutes and other government initiatives aimed at enhancing national technological competitiveness. Even though strategic importance is attributed to government efforts to stimulate innovative activities (King, Gurbaxani, Kraemer, McFarlan, Raman, \& Yap, 1994), especially in developing countries (Breznitz \& Murphree, 2011), in market economies these are private enterprises that are credited with the ability to drive technological change (OECD, 1997). Private companies ${ }^{4}$ are involved in each stage of the innovation process, from invention to turning new ideas into functional forms and, finally, to commercialising them accordingly. Looking beyond the efforts of the Russian government to enhance the nation's technological competitiveness, the involvement of the private sector in innovation presents an important area of research. This area

\footnotetext{
${ }^{1}$ Innovation is defined as a process of three overlapping stages: Invention, innovation, and diffusion (King, Gurbaxani, Kraemer, McFarlan, Raman, \& Yap, 1994, p. 140). The Oslo Manual, the guideline for measuring and collecting innovation data, provides a comprehensive definition of technological product and process innovations (TPP) (OECD \& SOEC, 1996, p. 31).

2 Russia has been classified as an 'emerging economy' thanks to its rapid growth rate in the last decades (growth rates surpassing those of developed economies being one of the defining features of emerging markets). However, its recent economic growth could be attributed primarily to high commodity prices (Hidalgo, 2013, pp. 5-7).

${ }^{3}$ The definition and origin of the concept are discussed extensively in OECD $(1997,1999)$ and Carlsson (2006). The main elements of a well-functioning NIS, including the collective efforts of the private sector, universities, science and technology (S\&T) institutes, government policies and regulations, as well as cultural traditions, produce a 'distinctive national character of innovation system' (Carlsson, 2006, p. 63). Based on this systematic view, innovation is generated in the midst of a complex interplay between cooperating and at the same time competing forces through an exchange of knowledge, people, and resources (OECD, 1997, p. 12).

${ }^{4}$ For example, the American model of innovation is characterized by an active involvement of private actors that channel ideas into the marketplace (Segal, 2011).
} 
calls for more empirical investigations, not only at the firm level (Kuznetsova \& Roud, 2014), but also at the macro level. In the context of developing economies and emerging economies, where NIS linkages between different actors might be missing or there is a lack altogether of a 'coherent strategy to integrate the fundamental ingredients' (Dzisah \& Etzkowitz, 2008, p. 103), the simple question about the main actors involved in inventive activity, and the value of their contribution, is still relevant. Patent statistics can provide valuable insights into the nature and sources of inventive output at the national level.

Third, we discuss the link between entrepreneurship and innovation. Who initiates a patent application is relevant to its further commercialisation, an entrepreneurial act which implies practical application, economic realisation, and profit extraction. This is a private enterprise's raison d'être. The motives of individual inventors and, most importantly, their capabilities might not fully fit this entrepreneurial model. Furthermore, there is a lack of empirical research on the link between entrepreneurship and innovation at the macro level, especially in emerging or transitional economies ${ }^{5}$. Essentially, it is a rarely discussed theme by entrepreneurship scholars ${ }^{6}$ (Manev \& Manolova, 2010, p. 77). Manev and Manolova (2010, p. 82) call for more empirical research to investigate the process of innovation in the context of transitional economies. Therefore, we explore the nature of entities involved in inventive activities in Russia by focusing on their economic and technological utility and, correspondingly, potential contribution to economic development. This angle is inspired by the debate on the differences between individual inventors and firms, which we discuss in the first section of the literature review. Additionally, we explore the difference between domestic companies and foreign subsidiaries of multinational enterprises (MNEs). The third section of the literature review addresses the idiosyncrasies of the Russian case. The value of patent applications or their potential economic utility is determined by references to the invention found in subsequent patents. The methodology section discusses the sources of patent statistics and procedures. Then we apply regression analysis and one-way ANOVA comparing different groups of applicants in Russia based on their citation record.

\section{LITERATURE REVIEW}

\section{Individual Inventors vs Firms}

Innovation does not happen by chance, it is driven by entrepreneurship (Munoz-Bullon, 2016), which is an integral part of the innovation process, as innovation involves not only the stage of invention or conceptualisation of a new idea, but also (and this is the role that Schumpeter (1947, p. 152) ascribes to the entrepreneur) the stages of practical application and commercialisation. Thus, according to Schumpeter, there is a fundamental difference between the 'entrepreneur' and the 'inventor' (Schumpeter, 1947, p. 152), as they represent two distinct functions. Entrepreneurs turn inventions into innovations, but to achieve

\footnotetext{
${ }^{5}$ Manev and Manolova (2010, pp. 70-71) assign Russia to a transitional economy, i.e. transitioning from a centrally-planned to a market economy.

${ }^{6}$ There are some exceptions discussed in González-Benito, Muñoz-Gallego and García-Zamora (2015, pp. 155035-7-8). Most of the literature, which professes that entrepreneurship leads to innovation, focuses on developed rather than developing or emerging economies.
} 
their goals profit-driven entrepreneurs need resources, an appropriate business environment, and reward-oriented organisational backing: 'The major share of inventive activities finalized to economically exploitable technologies that goes on in contemporary capitalist societies is done in profit-seeking organizations with the hope and expectation of being economically rewarded, if that work is successful' (Dosi \& Nelson, 2013, p. 15). Looking at the development of the market for technology from a historical perspective, Lamoreaux and Sokoloff (1996) identify two modes of thinking about the process of invention: the nineteenth-century early period, when inventors were viewed as creative individuals undertaking the exploitation of their inventions themselves, and the later twentieth-century period, when the patent system and the market for trade in technology matured, the process of invention became more specialised, the costs of inventive activity rose, and firms became more involved in generating, appropriating, and commercialising technology. In modern times, as innovation becomes a prerogative, a source of competitive advantage, and a major expense for profit-driven companies, individuals frequently lack resources to commercialise their inventions successfully (Hunter, 2012, p. 85).

A number of studies argue that patents commercialised by firms have a higher probability of success than those commercialised by individuals. For example, Braunerhjelm and Svensson (2010, p. 434) contend that invention and innovation should be undertaken as separate activities, which in effect substantiates the Schumpeterian position. Another example is the argument in Singh and Fleming (2010), according to which lonely inventors (especially those working outside of an organisation) generate patents that have a low technological, economic, or social impact, measured as citation statistics. Dahlin, Taylor and Fichman (2004) conclude, based on the analysis of US patents in the tennis racket industry, that there is a great deal of uncertainty associated with the value of innovation by independent inventors ${ }^{7}$. In his historic overview of the nature and quality of patents from Israel, Trajtenberg (1999, p. 17) discovered that in the period between 1968 and $1997,37 \%$ of Israeli patents were so-called unassigned patents or patents filed by individuals. His conclusions were that these patents may ultimately find their way to 'successful commercial applications (and many do), but they typically face much higher uncertainty than corporate assignees' (Trajtenberg, 1999, p. 16). Furthermore, corporations are in the position to leverage better internal spillovers produced by these innovations and, therefore, corporate patents have higher economic potential (Trajtenberg, 1999, p. 16).

At the same time, Amesse, Desranleau, Etemad, Fortier and Seguin-Dulude (1991, p. 26), based on a mail survey of individual inventors in Canada, identified that a large portion of individual inventors were entrepreneurs. About $46 \%$ were self-employed and $65 \%$ of these owned a small business with employees. Furthermore, $43.3 \%$ of individual inventions were commercialised and in $42.7 \%$ of cases, the invention was commercialised in the company owned by the inventor. Of course, the institutional environment in Canada is more

\footnotetext{
7 Dahlin et al. (2004) measure the value of patents based on a number of indicators. One of them is 'impact', namely the number of times a patent has been cited in subsequent tennis racket patents. Other indicators include the level of detail and scope, which are captured by a detailed technical content analysis of industry-specific patents. The measure of success is payments of maintenance or renewal fees. This project does not attempt to evaluate the technical characteristics of PCT patents coming from a variety of industries. We also do not possess renewal or maintenance fee statistics, since we deal with relatively recent patent applications. Thus, we stick to the citations' measure as an indication of a patent's technological and economic merit.
} 
small business-friendly than in many emerging markets, where entrepreneurs might not enjoy the same opportunities. However, the dual role of Canadian inventors as entrepreneurs in almost $50 \%$ of cases of individual patents and the high level of their commercialisation are sobering facts especially in light of the scepticism about the economic output of individual patents. Weick and Eakin $(2005$, p. 5), based on the survey of 351 individual inventors in the US, conclude that $39 \%$ of respondents generated sales from their inventions. Most inventors tried to bring their inventions to the market either through selling or licensing patent rights or via the inventor's own company (inventor as an entrepreneur). Weick and Eakin (2005, p. 14) conclude, however, that those who licensed their inventions vis-àvis those who attempted self-commercialisation succeeded at generating higher sales.

Agiakloglou, Drivas and Karamanis (2014) addressed the commercialisation of individual patents via sale and licensing to a 'large entity' implying a larger company (not a small and medium-sized enterprise (SME)). Agiakloglou et al. (2014, p. 3) found that twelve percent of US patents between 1990 and 2000 assigned to individuals were commercialised by being sold or licensed to larger businesses. This implies that the rest of individual patents have been either commercialised by inventors themselves or not commercialised at all. Thus, the economic output of individual patents remains ambiguous. Inspired by this debate, the current project hypothesizes that patents filed by individuals have lower economic utility than patents filed by firms, and it compares the impact (measured as the number of times a patent is referenced) of individual and firm patent applications from Russia.

\section{Domestic Firms vs Foreign Subsidiaries}

According to Dunning's OLI paradigm, in order to overcome lack of knowledge of the local market and institutional specifics, and to be able to compete successfully in foreign markets, MNEs must have and harness a combination of (O)wnership, (L)ocalisation and (I)nternalisation advantages. Ownership advantages come from possessing and managing income-generating assets (Dunning, 2001, p. 176). The ability to leverage and successfully manage innovation across borders is part of the $O$ advantages arsenal, especially in the later stages of the investment development path (IDP) achieved by host economies. More advanced stages of IDP imply that MNEs internationalise to seek out markets, efficiencies, and asset augmentation in desirable destinations rather than, as in earlier stages, resources or cheap labour (Narula \& Dunning, 2010, pp. 267-268). In the later stages of IDP, a host country-specific, innovation-stimulating infrastructure determines localisation advantages for knowledge- and learning-driven MNEs. Thus, the level of innovation-driven advantages that an MNE enjoys vis-à-vis indigenous firms depends on the stage of IDP that a host economy has reached. The later stages of IDP imply that a host economy has matured in terms of striking a balance between incoming and outgoing $\mathrm{FDI}^{8}$, competitive markets, conducive institutional infrastructure (including the protection of intellectual property rights (IPR)), and innovation-supporting government strategies (Narula \& Dunning, 2010, p. 268). All of these are the components of a well-functioning NIS, which itself plays an important role in attracting R\&D investment, as empirically confirmed especially for developed economies (Veliyath \& Sambharya, 2011, p. 422). In a country that has not reached the advanced stages of IDP we should expect that local subsidiaries of foreign

\footnotetext{
${ }^{8}$ Capital flight, which is frequently the case in Russia, does not qualify as a value-adding FDI.
} 
MNEs would demonstrate a higher propensity for innovation than domestic counterparts. These subsidiaries can draw not only from the local expertise (host country human capital can be a useful source of knowledge especially for adjusting to the local market needs), but also from internal networks. The embeddedness in a geographically dispersed internal innovation network frequently makes MNEs more technologically competitive than companies in host environments, especially in developing markets.

\section{The Russian Case}

Russia represents an interesting case to investigate the role of individual inventors, visà-vis firms in technological progress. On the one hand, Russia's invention record historically includes a long list of achievements-the result of the brilliance of individual inventors (Graham, 2013). The country inherited a well-developed education system from the Soviet Union, its science base is still strong, and the government commits substantial resources to R\&D (Filippov, 2011, p. 187). On the other hand, according to Filippov (2011), Russia has little success in converting ideas into marketable innovations and commercialising them, which can be explained by the unstable business environment forcing firms to focus on short-term goals. Based on a large-scale monitoring survey of the behaviour of innovative companies, conducted by the Higher School of Economics, only nine percent of manufacturers in 2012 looked at innovation as a means of achieving competitive advantage ( $26 \%$ in the information technology sector) (Kuznetsova \& Roud, 2014, pp. 11-12). Long-term investments into innovation are seen as too risky, especially for small firms. Furthermore, there is almost no early stage venture capital infrastructure in Russia (Gianella \& Tompson, 2007, p. 29). As a consequence of recent economic sanctions against the Russian government, Russia's own efforts to control the inflow of foreign capital, and the overall deteriorating economic conditions, investment volumes and opportunities for the access to foreign venture capital have decreased substantially: ' $[T]$ he volume of private funds in the venture market has decreased by more than a halffrom the beginning of the year [and] corporate funds have cut their support for projects by $61 \%$ ' (IET, 2015, p. 336).

In effect, the government remains the main source of funding for innovation (Todosiichuk, 2011, p. 11), and this funding is mostly channelled to the public sphere. The leading role of the Russian government in technological transformation is the product of its Soviet legacy and the enduring characteristics of its NIS. About 60\% of R\&D activities in Russia, according to 2007 data, are publicly financed (Podmetina, Smirnova, Väätänen, \& Torkkeli, 2009, p. 296). Furthermore, if seeking to broaden the definition of the public sphere to include not only state institutes, but also companies that are majority stateowned, it can be estimated that $98 \%$ of total budgetary funding for science is channelled to the public sector (IET, 2006, p. 244). This demonstrates the imbalanced nature of Russia's NIS and confirms that 'its entrepreneurial sector is almost invisible, while receiving, in effect, no direct support from the state' (IET, 2006, p. 244).

There is a lack of research dedicated to individual inventors in transitional economies, with Ivančič, Podmenik and Hafner (2014) being one of the very few studies to tackle the issue. The authors discuss the resources available to individual inventors in Slovenia ${ }^{9}$,

${ }^{9}$ Generally speaking, Russia and Slovenia share common historic experiences, including the recent example of drastic political and economic transformations in the post-socialist period. Unlike Russia, however, Slovenia had 
where individual inventors 'suffer from a deficiency of both opportunities and the necessary skills and competencies' to access formal NIS supportive networks, such as universities, research institutes, technology parks, etc. (Ivančič et al., 2014, p. 249). In other words, individual inventors are operating outside of NIS and cannot therefore benefit from its financial or social infrastructure. We can subsequently draw parallels with the case of Russia, where firms and especially individuals do not have much access to either public or private funding. To conclude, since the business and institutional environment in Russia is challenging enough for the private sector to be able to engage efficiently in innovation, then the successful economic output of individual inventors must be particularly unrealistic to expect. We will test this assumption by looking at different categories of PCT inventors and the value of their ideas, measured as citations in other patents.

At the system level, Russia has not reached this level of development, which characterizes the so-called 'knowledge economy' stages of IDP. The main actors involved in innovation activities in Russia, namely publicly-funded research institutes and universities, state-owned and state-controlled enterprises, and the private sector, are isolated and uncoordinated (Ermasova \& Ermasov, 2013). As a result, the mechanisms of knowledge transfer to the market are performing poorly, the outcomes of research activities are not properly diffused, and the system of S\&T institutions (with the Academy of Russian Sciences on top) is disconnected from application (Gianella \& Tompson, 2007; Gokhberg, 2004; Subbotina, 2007; Todosiichuk, 2011). Russia displays higher proclivity toward fundamental science rather than toward applied and market-oriented innovation (Tseng, 2009, p. 32). The active involvement of the private sector in innovation requires the decentralisation of economic decision-making, which is not the case in Russia (Golichenko, 2011, p. 57); since the main player on the nation's innovation scene is the government. Indeed, innovation entrepreneurship, or the efforts of entrepreneurial firms to create new ideas, translate them into concrete applications, produce, and deliver to the customer is not sufficiently developed in Russia (McCarthy, Puffer, Graham, \& Satinsky, 2014, p. 245).

Since Russia has not reached the 'knowledge economy' stage, MNEs operating there, by definition, possess greater resources and capabilities of generating valueadding innovation than Russian firms. Indeed, MNEs are credited with the superior ability to organise innovation activities across their 'dispersed but interconnected international network' (Cantwell \& Piscitello, 2005, p. 3). They are setting up R\&D facilities in Russia, not because of the quality of its NIS but because it offers affordable engineering and other technical carders as well as government contracts ${ }^{10}$. Due to the innovation network management capabilities of MNEs, their global outreach, and the admitted limitations of the Russian NIS, we should expect better performance from those MNEs currently present in Russia than from domestic firms with respect to the ability to generate patent references.

to integrate into the EU community, which implied legal, institutional, and economic assimilation. Slovenia made significant progress in innovation, as it moved in 2015 into the category of 'innovation followers', or countries that approach the EU average, according to the 2015 Innovation Union Scoreboard (IUS) (European Commission, 2015 , p. 10). Slovenia is the only ex-socialist country in this category. Taking the innovation progress achieved by Slovenia into consideration, Russia presents even a more of a discouraging case for private innovation initiatives. ${ }^{10}$ For instance, Siemens has won numerous government contracts and worked in close cooperation with a number of state corporations, including Rosatom (Womp, 2009), Russian Railways, RosNeft, etc. (Siemens, 2016). 


\section{MATERIAL AND METHODS}

\section{Data Sources: WIPO Statistics Database}

This project uses statistics on patent applications filed through the Patent Cooperation Treaty (PCT) mechanism and published by the World Intellectual Property Organization (WIPO) in 2013. WIPO assembles data on patent filings and grants from national and regional IP offices in its comprehensive statistics database PATENTSCOPE. A patent is a set of exclusive rights granted for a period of usually 20 years (WIPO Glossary, 2015).

Patent statistics can be used as a measure of inventive activity, since they indicate (as a minimum requirement) the commitment of an applicant to pursue the practical application of an idea (Griliches, 1990 p. 1669). As a result, patents can serve as measurable proxies for inventive activity and, to some degree, innovative input, since they account for the first stages of the innovation process-the generation and conceptualisation of novel ideas. There is a fundamental difference, of course, between a patent application and a granted patent. Granted patents are registered and have gone through the process of assessment by national or international patent offices. Patent rights are granted by patent authorities when they represent a new and original technological contribution (Tseng, 2009, p. 30; Braunerhjelm \& Svensson, 2010, p. 424). A patent application, however, is just an expressed intention to seek IP rights protection for a particular invention, hence the limitation of using patent applications vis-àvis granted patents as a measure of invention.

PCT patent application data are, however, useful for a number of reasons. First, based on the description of a patent filing, one can deduce the nature of the applicants and divide them into categories. There are three categories of individuals or organisations mentioned in the patent application: applicants, inventors, and agents. Applicants file an application and possess IPRs when a patent is granted. Inventors are usually individuals who conceived an invention, and agents provide legal and technical support to file an application. For the purposes of this project, when an application was filed by an individual or a group of individuals (as applicants), it was classified as an 'individual application'. Thus, depending on the nature of an applicant (whether an individual or a legal entity, such as a company or a research institute), patents were assigned to different categories.

Second, PCT allows applicants to file for patent protection in 151 countries simultaneously (WIPO, 2017), which makes PCT statistics (due to the wide geographical application) a perfect indicator of internationally-oriented patenting activity. By filing a PCT application, applicants, by definition, announce their intent to pursue IPRs abroad. The PCT procedure includes several stages. The first phase involves filing with a national or regional patent office or WIPO. A patent's 'nationality' is based on where the application was filed and is determined by a two-letter country code assigned to each application. The country code for applications filed from Russia is 'RU'. Then an International Searching Authority (ISA) evaluates the patentability of the invention based on three criteria: novelty, inventiveness, and industrial applicability. After an ISA produces a written report or after 18 months since the application, the contents of the application are made public via their publication on the WIPO website. Lastly, an applicant pursues the grant of a patent directly with the national (or regional) patent offices of the countries where the protection is sought (WIPO, 2014). 


\section{Procedures}

This project looked at the total number of resident ${ }^{11}$ PCT applications from Russia published on PATENTSCOPE, the WIPO Statistics Database, in 2013. The fact that the applications were published indicates that they must have been screened by an ISA and a written opinion was produced. Each application was investigated individually; the total number of applications in 2013-1.075-was divided into six types of applicant entities involved in invention activities in Russia: an individual, a foreign subsidiary/foreign-registered firm ${ }^{12}$, a Russian company, a university, and a research centre/institute. The objective of dividing patent applications into these groups was to inspect the structure of the NIS participants and understand the landscape of inventive activity in Russia.

Looking at patent citations as a measure of a patent's value with regard to its economic and technological impact, we identified the contribution of each group to the national-level inventiveness. Even though a frequency of citations per patent is not an accurate indicator of its technological or social value (Jaffe \& Trajtenberg, 2002 p. 28), it is nevertheless an important indicator of the technological footprint of the patent (Hall, Jaffe, \& Trajtenberg, 2000, p. 4). The cross-sectional nature of our data (patent statistics for 2013) ensures that all patents in the sample have an equal chance of attracting attention and being referenced. The year 2013 was chosen to allow some time for applications to be noted and cited. We used Google Patents to trace down references to each PCT patent publication on our list of 1.075, following which we compared the means of references for each application category using a linear regression to account for differences with regard to possible practical or economic utility expressed as citations. After dummy coding of the independent variable, five dummy variables were created with 'foreign subsidiary' being held constant as a reference group. We also used one-way analysis of variance (ANOVA) to account for mean differences in the categorical variable (six categories of patent applicants) as a predictor and a continuous variable (number of citations) as a dependent variable. Depending on how the variables are operationalised, the use of ANOVA is appropriate when comparing the means of several categories or groups (Sweet \& Grace-Martin, 2008, p. 124).

\section{RESULTS AND DISCUSSION}

\section{Domestic and International Patenting in Russia}

Table 1 provides the basic descriptive statistics of Russian patenting activity from 1999 to 2016, including annual data on the total number of resident applications and applications abroad, total number of applications granted (domestically and by foreign IP officers), and PCT application statistics. These data were taken directly from the Russian country profile in WIPO Statistics database and utilised here to illustrate the general patterns of Russian domestic and foreign patent filings. The number of 'applications abroad' as a proportion of

\footnotetext{
${ }^{11}$ Resident applications are filed by country residents at their national patent office. 'Applications abroad' are filed at a foreign office. For exact definitions of what constitutes a 'resident application' and an 'application abroad', please see WIPO Glossary (retrieved on 15 February, 2015 from http://www.wipo.int/ipstats/en/help/) 12 We came across a number of companies that were assigned a Russian patent code-RU-despite having a foreign address, for instance in British Virgin Islands. We categorised these companies as 'foreign registered'.
} 
the total number of applications (resident and abroad) is nine percent on average, from 1999 to 2016. Even though the number of applications abroad increased over the years from three percent (from total) in 1999 to $15 \%$ in 2016, the overwhelming majority of patents in Russia are filed domestically. PCT applications constitute $37 \%$ (on average) of applications abroad. Interestingly, PCT patenting as a percentage of filings abroad decreased from $69 \%$ in 1999 to $24 \%$ in 2013 , and then to $18 \%$ in 2016 , which may indicate a limitation of using PCT applications as a measure of international patenting for Russia. PCT patent filings represent less than half of all internationally-oriented applications from Russia. It is important to note that roughly half of all applications abroad or applications filed by Russian inventors in other jurisdictions (including PCT applications) were granted patent protection, which means that the other half did not meet the criteria of corresponding national patent offices with respect to novelty, inventiveness, and industrial applicability, in turn decreasing even further the pool of commercially viable international inventions.

Table 1. Inventive Activity in Russia, 1999-2016

\begin{tabular}{|c|c|c|c|c|c|c|c|c|}
\hline \multirow[b]{2}{*}{ Years } & \multicolumn{3}{|c|}{ Patent applications } & \multicolumn{3}{|c|}{ Patents granted } & \multirow[b]{2}{*}{$\begin{array}{l}\text { PCT } \\
\text { applica- } \\
\text { tions }\end{array}$} & \multirow[b]{2}{*}{$\begin{array}{c}\% \text { of PCT } \\
\text { applications } \\
\text { from Abroad }\end{array}$} \\
\hline & $\begin{array}{l}\text { Resi- } \\
\text { dents }\end{array}$ & Abroad & $\begin{array}{c}\% \text { of } \\
\text { Abroad } \\
\text { from total }\end{array}$ & $\begin{array}{l}\text { Resi- } \\
\text { dents }\end{array}$ & Abroad & $\begin{array}{c}\% \text { of } \\
\text { Abroad } \\
\text { from total }\end{array}$ & & \\
\hline 1999 & 19.900 & 691 & $3 \%$ & 15.362 & 383 & $2 \%$ & 478 & $69 \%$ \\
\hline 2000 & 23.377 & 716 & $3 \%$ & 14.444 & 386 & $3 \%$ & 533 & $74 \%$ \\
\hline 2001 & 24.777 & 880 & $3 \%$ & 13.779 & 445 & $3 \%$ & 557 & $63 \%$ \\
\hline 2002 & 23.712 & 787 & $3 \%$ & 15.140 & 454 & $3 \%$ & 540 & $69 \%$ \\
\hline 2003 & 24.969 & 675 & $3 \%$ & 20.621 & 516 & $2 \%$ & 587 & $87 \%$ \\
\hline 2004 & 23.118 & 1.922 & $8 \%$ & 19.214 & 1.130 & $6 \%$ & 519 & $27 \%$ \\
\hline 2005 & 23.796 & 2.152 & $8 \%$ & 19.556 & 1.263 & $6 \%$ & 658 & $31 \%$ \\
\hline 2006 & 28.070 & 2.505 & $8 \%$ & 19.238 & 1.203 & $6 \%$ & 696 & $28 \%$ \\
\hline 2007 & 27.716 & 2.773 & $9 \%$ & 18.616 & 1.874 & $9 \%$ & 735 & $27 \%$ \\
\hline 2008 & 27.936 & 3.159 & $10 \%$ & 22.421 & 1.738 & $7 \%$ & 802 & $25 \%$ \\
\hline 2009 & 25.824 & 3.035 & $11 \%$ & 26.438 & 1.632 & $6 \%$ & 736 & $24 \%$ \\
\hline 2010 & 29.022 & 3.815 & $12 \%$ & 21.783 & 1.850 & $8 \%$ & 814 & $21 \%$ \\
\hline 2011 & 26.879 & 4.585 & $15 \%$ & 20.475 & 1.704 & $8 \%$ & 1.009 & $22 \%$ \\
\hline 2012 & 29.174 & 5.205 & $15 \%$ & 22.637 & 1.763 & $7 \%$ & 1.114 & $21 \%$ \\
\hline 2013 & 29.120 & 4.945 & $15 \%$ & 21.520 & 1.845 & $8 \%$ & 1.191 & $24 \%$ \\
\hline 2014 & 24.370 & 4.142 & $15 \%$ & 23.305 & 2.742 & $11 \%$ & 948 & $23 \%$ \\
\hline 2015 & 29.567 & 4.225 & $13 \%$ & 22.753 & 2.245 & $9 \%$ & 876 & $21 \%$ \\
\hline 2016 & 27.136 & 4.765 & $15 \%$ & 21.292 & 2.945 & $12 \%$ & 851 & $18 \%$ \\
\hline STDEV & 2.684 & 1.623 & & 3.417 & 792 & & 211 & \\
\hline Mean & 26.026 & 2.832 & $9 \%$ & 19.659 & 1308 & $6 \%$ & 758 & $37 \%$ \\
\hline
\end{tabular}

Source: adopted from Country Profiles, Russia, WIPO Statistics Database. Retrieved on December 4, 2017 from http://www.wipo.int/ipstats/en/statistics/country_profile/profile.jsp?code=RU

The fact that the overwhelming majority of patent applications filed in Russia seek domestic protection, provide empirical basis for the arguments posited by Ermasova and Ermasov (2013), according to whom many Russian firms engaged in innovation are stateowned or state-controlled and receive funds directly from the government. These companies and scientists working for state-funded research institutes within the Russian S\&T 
system tend to apply for patents domestically (2013, p. 26). High levels of domestic patenting are an indicator that Russian inventions might not be patentable internationally, 'since the inventions may not be unique and may only serve as a means to block the importation of foreign produced goods' (Filippov, 2011, p. 189). The recognition of IPRs is easier to achieve domestically. The Russian patent law that de jure recognizes that inventions must be novel in practice fails to prevent the patenting of copycat inventions that do not differ significantly from the original (Gianella \& Tompson, 2007, p. 20). From this perspective, patent applications filed abroad (and especially PCT applications, which imply multiple target jurisdictions) can be interpreted as an entrepreneurial attempt to internationalise Russian products and ideas. This makes the task of identifying who actually files PCT applications in Russia even more pertinent. The nature of agents engaged in international patenting has implications for understanding the dynamics of Russia's NIS and, most importantly, the potential economic and technological impact of this patenting activity. As discussed above, when an international application is filed by a company, we have more grounds to expect a potential economic realisation of this patent.

\section{Composition of PCT Filings}

This article explored the 1.075 PCT applications from Russia published by WIPO in 2013. From the total list of all PCT applications (over 200 000) published in 2013 we identified a sample of Russian PCT filings based on the two-letter country code (RU). As Figure 1 shows, the majority of international or PCT applications from Russia-52\%-were produced by individuals. The proportion of Russian companies in PCT patenting in 2013 was $27 \%$, with $16 \%$ constituting the subsidiaries of MNEs in Russia and other foreign companies. The rest of the PCT patents were generated by federal agencies, research centres, and universities, which is, in actuality, an insignificant contribution. Thus, the actors that are traditionally considered to be active participants of a well-functioning NIS, i.e. universities, government-funded research institutes, federal agencies, etc., play a marginal role in international patenting in Russia (despite generous government funding of public research institutions). Domestic companies, compared to individuals, also play a secondary role. This result confirms the conclusion that invention in Russia has historically been a 'lonely' affair, exemplified by the fate of inventors like Mikhail Kalashnikov, who never properly capitalised on their inventions (Graham, 2013). Obviously, the tradition lives on and promises bleak prospects for the Russian NIS. The finding, based on our data for 2013 , that $52 \%$ of Russian PCT patents were filed by individuals is an alarming sign for the prospects of their commercialisation, since it is unclear who will apply and bring these inventions to the market during the next stages of the innovation process. This indicates the weak entrepreneurial potential of these patents. Table 2 provides statistics on the ten most prolific applicants in 2013. The high patenting record of a number of individuals is comparable to the number of applications filed by foreign research centres in Russia (Intel or Siemens), companies registered abroad (in this case in British Virgin Islands) such as Rawllin International Inc., and domestic companies, for example Parafarm.

Individuals engage in internationally-oriented patenting activity twice as actively as domestic companies. Theoretically, a PCT application must be part of an internationalisation strategy of innovation, and it is the search for new markets that pushes firms to internationalise. Internationalisation and innovation are the two main strategies employed to 
achieve growth ascribed to profit-driven enterprises (Hagen et al., 2014, p. 111). Technology-intensive companies pursue internationalisation strategies because they seek larger international markets to earn returns on their investment (Yamakawa, Peng, \& Deeds, 2008 , p. 67), whilst commercialisation is used to receive returns on investment and gain competitive advantage in the market 'for a particular product, process, or service' (U.S. Congress, 1995). Commercialisation of inventions (mostly executed by the private sector) is also part of the reward system. Consequently, the fact that internationally-oriented patenting activity in Russia is pursued mostly by individual inventors is noteworthy and sheds light on the nature of Russia's NIS. Ultimately, the logic behind IP protection is to create an incentive structure for inventors. As noted by Lu, Eric and Peng (2008), the so-called 'spontaneous innovation' generated by 'hobbyists' who do not benefit financially from their inventions can be detrimental for a continuous innovation effort.

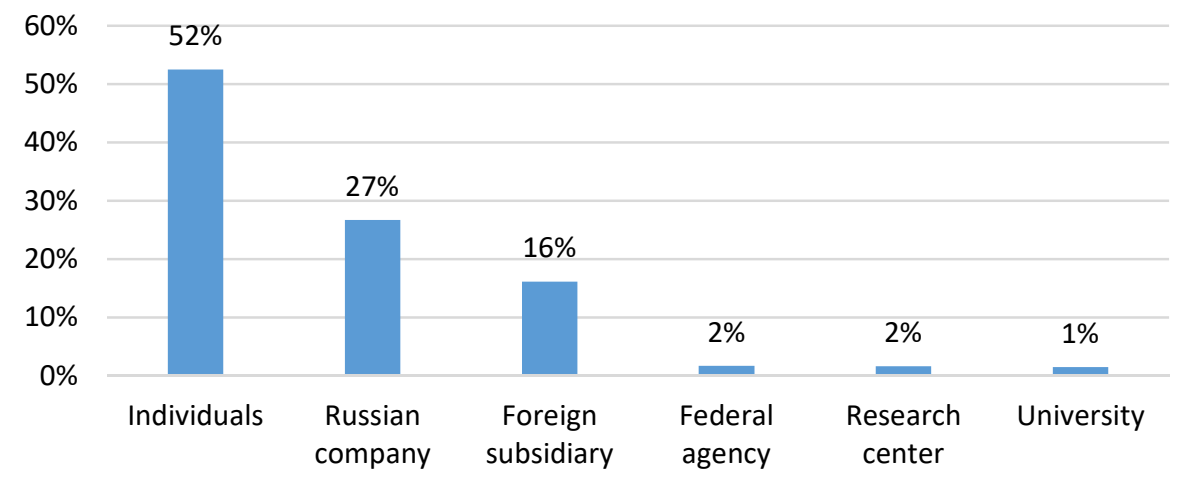

Figure 1. Percentage of Russian PCT applications in different categories of applicants published by WIPO in 2013

Source: WIPO Statistics Database, PATENTSCOPE. Retrieved in November-December, 2015 from https://patentscope.wipo.int/search/en/search.jsf

Table 2. Top Ten PCT Applicants for Applications Published by WIPO in 2013

\begin{tabular}{|c|l|r|c|}
\hline No. & PCT top applicants (published in 2013) & Type of applicant & $\begin{array}{c}\text { Number of } \\
\text { publications }\end{array}$ \\
\hline 1 & RAWLLIN INTERNATIONAL INC & Foreign subsidiary/foreign- registered & 34 \\
\hline 2 & SIEMENS AKTIENGESELLSCHAFT & Foreign subsidiary/foreign- registered & 29 \\
\hline 3 & INTEL CORPORATION & Foreign subsidiary/foreign- registered & 23 \\
\hline 4 & GENERAL ELECTRIC COMPANY & Foreign subsidiary/foreign- registered & 19 \\
\hline 5 & M.P.E. & Individual & 14 \\
\hline 6 & $\begin{array}{l}\text { OBSHESTVO S OGRANICHENNOJ } \\
\text { OTVETSTVENNOSTJU “PARAFARM” }\end{array}$ & Russian company & 11 \\
\hline 7 & B.P.A & Individual & 10 \\
\hline 8 & BAKER HUGHES INCORPORATED & Foreign subsidiary/foreign- registered & 9 \\
\hline 9 & $\begin{array}{l}\text { BAUMAN MOSCOW STATE TECHNICAL } \\
\text { UNIVERSITY (BMSTU) }\end{array}$ & $\begin{array}{l}\text { Russian company } \\
\text { DIS PLUS }\end{array}$ & 8 \\
\hline & SOCIETY WITH LIMITED LIABILITY & & 8 \\
\hline
\end{tabular}

Source: WIPO Statistics Database, PATENTSCOPE. Retrieved in November-December 2015 from https://patentscope.wipo.int/search/en/search.jsf 


\section{Impact of Different Categories of PCT Applications}

The results of the linear regression analysis are presented in Table 3. The coefficients for the five dummy variables (PCT applications by individuals, companies, federal agencies, universities and research centres) are displayed in the first column. The intercept coefficient at 0.47 is the mean of the 'foreign subsidiaries' category, which is a reference group. Table 3 shows that individuals (IND) and companies (COM) coefficients diverge significantly from the reference group - foreign subsidiaries (FS). Similar to ANOVA, this regression model compares means of patent citations in different categories of applicants (Grace-Martin, 2018). A regression reports one mean for FS as an intercept and the differences between this group and all other means. Thus, the average number of references to each category of applications significantly differs in two pairs of categories: individual and foreign subsidiary applications ${ }^{13}$ and company and foreign subsidiary applications. In other words, individuals and firms in Russia attract fewer citations on average than foreign subsidiaries. The mean differences between individual and foreign subsidiary patent applications, as well as between company and foreign subsidiary applications, are statistically significant with significance levels below 0.01 . Even though federal agency, university or research centre filings seem to differ in terms of mean references from foreign subsidiaries, their mean differences are not statistically significant ${ }^{14}$.

On average, there are more references to patents filed by foreign subsidiaries in Russia than to individuals or domestic company filings. These results confirm the assumptions that both Russian-origin individual and firm applications have attracted on average fewer references than filings pursued by foreign subsidiary/foreign registered companies. The value of foreign subsidiary applications, based on patent references, is superior to the potential technological or economic impact of both domestic individual and company patent applications. As noted above, this can be explained by the superior innovation-based ownership advantages of foreign MNEs, including the ability to plug into intra-company knowledge depositories and networks on a global scale. This presents an undeniable advantage, especially in the context of host economies like Russia, which have not reached the advanced levels of the so-called 'knowledge economies'.

Table 4 presents the results of a one-way ANOVA, which displays the means of the number of references to each category of patent application. The model is statistically significant with $p$ value less than 0.001 and $F=4.114$. There is no significant difference in the average number of references by Russian individual and firm applications. As discussed above, both categories of PCT applicants have limited access to funding, either in the form of venture capital or government support. Firms' international patenting in Russia is, indeed, deficient based on two parameters: The number of applications vis-à-vis individual applications and low reference performance. The poor international innovation performance of Russian firms can be explained by an unsupportive institutional environment. In developing countries entrepreneurial companies (including

\footnotetext{
${ }^{13}$ The group includes the so-called 'foreign-registered' applicants, but from this point on this category is referred to as 'foreign subsidiaries' or FS.

14 This can be attributed to the low number of applications filed by these categories of applicants in our sample. We admit the limitation of cross-sectional design in this respect.
} 
those that engage in innovation) operate in volatile environments with 'uncertain property rights and underdeveloped markets for goods and capital' (Ahlstrom \& Bruton, 2010 , p. 537). Consequently, entrepreneurial firms, reportedly the major drivers of innovation in countries such as the US (Segal, 2011) or Israel (Breznitz, 2007), are disadvantaged by deficiencies in the institutional environment such as that found in Russia. This applies particularly to small and medium-sized businesses (SMEs), since innovating SMEs in developing economies face a number of challenges, i.e. an unstable and risky institutional environment and an internal lack of resources; thus, their engagement in innovation is inherently risky (Zhu, Wittmann, \& Peng, 2011).

Table 3. Results of Linear Regression Analysis for Five Categories of Patent Applicants and Foreign Subsidiaries (FS) as Reference Group

\begin{tabular}{|l|r|r|r|}
\hline \multicolumn{1}{|c|}{ Category of Applicants } & Coefficients & Coefficients Std. Error & \multicolumn{1}{c|}{ Sig. } \\
\hline Intercept (Foreign subsidiary (FS)) & $\mathbf{0 . 4 6 8}$ & 0.065 & $\mathbf{0 . 0 0 0}$ \\
\hline Individual (IND) & $\mathbf{- 0 . 3 2 5}$ & 0.074 & $\mathbf{0 . 0 0 0}$ \\
\hline Company (COM) & $-\mathbf{0 . 2 9 7}$ & 0.082 & $\mathbf{0 . 0 0 0}$ \\
\hline Federal agency (FED) & -0.302 & 0.211 & 0.153 \\
\hline University (UNI) & -0.406 & 0.223 & 0.069 \\
\hline Research Centre (RC) & -0.174 & 0.217 & 0.422 \\
\hline
\end{tabular}

Source: WIPO Statistics Database, PATENTSCOPE. Retrieved in November-December 2014 from https://patentscope.wipo.int/search/en/search.jsf, and Google Patents, retrieved between December 2016-January 2017.

Table 4. One-way ANOVA: Mean Differences of Patent Application References

\begin{tabular}{|c|c|c|c|c|c|c|c|c|}
\hline \multirow{2}{*}{$\begin{array}{c}\text { Category } \\
\text { of Applicants }\end{array}$} & \multirow{2}{*}{$\mathbf{N}$} & \multirow{2}{*}{ Mean } & \multirow{2}{*}{$\begin{array}{c}\text { Std. } \\
\text { deviation }\end{array}$} & \multirow{2}{*}{$\begin{array}{l}\text { Std. } \\
\text { error }\end{array}$} & \multicolumn{2}{|c|}{$\begin{array}{c}\text { 95\% confidence } \\
\text { interval for mean }\end{array}$} & \multirow{2}{*}{ Min } & \multirow{2}{*}{ Max } \\
\hline & & & & & $\begin{array}{l}\text { Lower } \\
\text { bound }\end{array}$ & $\begin{array}{l}\text { Upper } \\
\text { bound }\end{array}$ & & \\
\hline Individual (IND) & 564 & $0.14^{*}$ & 0.823 & 0.035 & 0.08 & 0.21 & 0 & 16 \\
\hline Company (COM) & 287 & $0.17^{*}$ & 0.655 & 0.039 & 0.09 & 0.25 & 0 & 5 \\
\hline Foreign subsidiary (FS) & 173 & $0.47^{*}$ & 1.208 & 0.092 & 0.29 & 0.65 & 0 & 7 \\
\hline Federal agency (FED) & 18 & 0.17 & 0.514 & 0.121 & -0.09 & 0.42 & 0 & 2 \\
\hline University (UNI) & 16 & 0.06 & 0.25 & 0.062 & -0.07 & 0.2 & 0 & 1 \\
\hline Research centre (RC) & 17 & 0.29 & 0.985 & 0.239 & -0.21 & 0.8 & 0 & 4 \\
\hline Total & 1075 & 0.2 & 0.858 & 0.026 & 0.15 & 0.26 & 0 & 16 \\
\hline
\end{tabular}

* Statistically significant at the 0.01 level (post hoc test (Tukey))

Source: WIPO Statistics Database, PATENTSCOPE. Retrieved between November-December 2014 from https://patentscope.wipo.int/search/en/search.jsf, and Google Patents, retrieved between December 2016-January 2017.

Another possible explanation for the limited participation of the private sector in internationally-oriented patenting in Russia is the low diversification of the Russian economy. Hydrocarbon-based fuel, including oil and natural gas, as well as distillation products represent the highest value of exports-about 346 billion USD (69.5\%) from the total value of Russian exports at about 498 billion USD in 2014 (Trade Map, 2015). Other value-contributing exports include iron and steel, precious metals, aluminium, copper, etc. Many resource sector companies are large, government-owned multinational corporations that do not feel much pressure to innovate (Filippov, 2011, p. 201). 


\section{CONCLUSIONS}

At the national level, a variety of public and private actors participate in the innovation process, and their collective efforts condition the effectiveness of a national innovation system (NIS). Based on the empirical evidence collected by this study, the main participants in international patenting in Russia are individual inventors, as the majority of international or PCT patent applications published by WIPO in 2013 were filed by individuals. Russian domestic companies play a secondary role. This tendency for individuals (52\%) rather than Russian companies $(27 \%)$ or even foreign corporations with research subsidiaries in Russia and other companies registered abroad (including companies founded by Russian nationals) (16\%) to apply for international patents has implications for the practical application and commercialisation of these inventions. 'Lonely inventors' operate outside of the NIS and might lack resources to put their inventions to practical use and then bring them to the market. They also, by definition, are not imbedded in organisational infrastructure, an advantage shared by firms (Coase, 1937) and have a limited ability to leverage linkages to the government, the main source of funding for $R \& D$ in Russia. Ultimately, this dynamics demonstrates the lack of entrepreneurial potential in Russia's NIS, where, at least with respect to PCT filings, patents have a lower chance of economic profitability, because the major driver of innovation, namely the private sector, lacks incentives to invent and patent.

Patents are an important measurement of inventive performance and, depending on who initiates the patenting process (an individual or an organisation), a valuable indicator of prospective benefits from innovation. Commercialisation embodies an act of entrepreneurship and serves as the key instrument for receiving economic rewards from invention. In addition, based on the structure of Russian PCT patenting activity dominated by individuals, it is a missing element of its NIS. The lack of motivation of Russian firms to engage in international patenting is directly linked to their institutional environment. The Russian innovation landscape is dominated by government-funded programmes and other forms of government financial support provided to research institutes and state-controlled businesses. The market for venture capital is virtually nonexistent and Russian businesses, especially SMEs, look at innovation as a risky undertaking in the climate of political and economic instability. That is why we failed to identify considerable differences between firm and individual PCT applications in Russia with respect to their economic utility. Both types of applications attract on average fewer citations than foreign MNEs' subsidiaries operating in Russia.

The superior position of foreign subsidiaries in Russia with regard to the potential economic utility of their applications, vis-à-vis their Russian counterparts and individual inventors, is evident based on the comparison of mean references to patent filings in different categories. Foreign subsidiary filings attract more references than Russian individual inventors or companies, which confirms the assumptions of the OLI paradigm that, due to the ability to manage innovation successfully across borders and leverage intra-company innovation networks, MNEs have an advantage over domestic companies in host economies such as Russia that have not reached an advanced 'knowledge economy' status.

Against this backdrop, individual inventors are pursuing IP protection abroad, which is an alarming sign of the process of invention diffusion. We can only guess that these 
individuals are driven by hopes of attracting foreign venture capital or being able to leverage their IP rights via technology licensing. Furthermore, as Griliches suggests, low real wages have something to do with the propensity of individuals to file patent applications $(1990$, p. 1696). As real wages rise, so does the opportunity cost of dealing with the patent system as an individual. This assumption has a direct relevance to Russia as a transitioning or emerging economy, where real wages are lower than in developed economies, which in turn pushes individuals toward economic self-realisation via inventive activity. The examination of the motives that drive individual inventors in Russia could become a focus of future research. Furthermore, since the limitation of this study is a short time span, future research could track patent citations over a longer period of time.

In sum, this project, based on the use of PCT applications as a source of insights into the internationalisation of innovation in a transitional economy, contributes by drawing the following conclusions. First, foreign subsidiaries operating in Russia attract more attention from subsequent patents in the form of references than their Russian counterparts or individuals, which implies the higher level of commercial and technical utility of these inventions. Second, the realisation and empirical confirmation that individual creativity is still a driving force behind Russia's international innovation performance is noteworthy. Private enterprise appears to play a secondary role in internationally-oriented patenting, so the entrepreneurial aspect of Russia's innovation internationalisation effort is weak, which testifies to the weakness of its NIS.

The ultimate recommendation in respect to policymaking that can be derived from this study is the necessity for a systematic approach addressing the needs and incentives of various contributors to the innovation process: venture capital, universities, publiclyfunded research institutes and, most importantly, firms. Our study demonstrates that individual invention is a strong participant in Russia's internationally-oriented patenting. Even though individual invention can theoretically channel ideas into the entrepreneurial effort by firms or other types of organisations, its immediate technological or economic utility is wanting precisely because the NIS might lack the necessary institutional or social infrastructure for embedding individuals into the business or academic networks and, thus, facilitating the appropriation and realisation of these ideas. Furthermore, on the receiving side, Russian business is poorly incentivised to pursue innovation domestically or internationally. The innovation capability of Russian business, small or large, must be prioritised and strengthened via creating the right incentives and providing a stable institutional and infrastructural foundation.

\section{REFERENCES}

Ahlstrom, D., \& Bruton, G.D. (2010). Rapid institutional shifts and the co-evolution of entrepreneurial firms in transition economies. Entrepreneurship: Theory \& Practice, 34(3), 531-554. https://doi.org/10.1111/j.1540-6520.2010.00373.x

Agiakloglou, C., Drivas, K., \& Karamanis, D. (2014). Individual inventors and market potential: Evidence from US patents. MPRA Paper No. 58838. Retrieved on 5 November, 2015 from https://mpra.ub.uni-muenchen.de/58838/1/MPRA_paper_58838.pdf

Amesse, F., Desranleau, C., Etemad, H., Fortier, Y., \& Seguin-Dulude, L. (1991). The individual inventor and the role of entrepreneurship: A survey of the Canadian evidence. Research Policy, 20, 13-27. https://doi.org/10.1016/0048-7333(91)90081-Z 
Braunerhjelm, P., \& Svensson, R. (2010). The inventor's role: was Schumpeter right?. Journal of Evolutionary Economics, 20, 413-444. https://doi.org/10.1007/s00191-009-0157-5

Breznitz, D. (2009). National institutions and the globalized political economy of technological change: An introduction. Review of Policy Research, 26(1-2), 1-11. https://doi.org/10.1111/j.1541-1338.2008.00388.x

Breznitz. D., \& Murphree, M. (2011). Run of the Red Queen: Government, Innovation, Globalization and Economic Growth in China. New Haven: Yale University Press.

Hall, B.H., Jaffe, A., \& Trajtenberg, M. (2000). Market value and patent citations: A first look. National Bureau of Economic Research (NBER) Working Paper Series 7741. Retrieved on 3 April, 2015 from http://www.nber.org/papers/w7741

Cantwell, J., \& Piscitello, L. (2005). Recent location of foreign-owned research and development activities by large multinational corporations in the European regions: The Role of spillovers and externalities. Regional Studies, 39(1), 1-16. https://doi.org/10.1080/0034340052000320824

Carlsson, B. (2006). Internationalization of innovation systems: A survey of the literature. Research Policy, 35, 56-67. https://doi.org/10.1016/j.respol.2005.08.003

Coase, R.H. (1937). The Nature of the Firm. Economica, New Series, 4(16), 386-405. https://doi.org/10.1111/j.1468-0335.1937.tb00002.x

Dahlin, K., Taylor, M.R., \& Fichman, M. (2004). Today's Edisons or Weekend Hobbyists: Technical Merit and Success of Inventions by Independent Inventors. Research Policy, 33, 1167-1183. https://doi.org/10.1016/j.respol.2004.06.003

Dosi, G., \& Nelson, R. (2013). The evolution of technologies: An Assessment of the state-of-the-art. Eurasian Business Review, 3(1), 3-46. https://doi.org/10.14208/BF03353816

Dunning, J. (2001). The Eclectic (OLI) Paradigm of international production: Past, present and future. International Journal of the Economics of Business, 8(2), 173-190. https://doi.org/10.1080/13571510110051441

Dzisah, J., \& Etzkowitz, H. (2008). Triple helix circulation: the heart of innovation and development. International Journal of Technology Management \& Sustainable Development, 7(2), 101-115. https://doi.org/10.1386/ijtm.7.2.101_1

Ermasova, N., \& Ermasov, S. (2013). Impact of Policy Risk on Innovation Activity in Russia. SAM Advanced Management Journal (07497075), 78(4), 23-45.

European Commission (2015) Innovation Union Scoreboard 2015. Maastricht Economic and Social Research Institute on Innovation and Technology (UNU-MERIT). Belgium.

Filippov, S. (2011). Innovation and R\&D in emerging Russian multinationals. Economics, Management \& Financial Markets, 6(1), 182-206.

Freeman, C. (1995). The national system of innovation in historical perspective. Cambridge Journal of Economics, 19, 5-24. https://doi.org/10.1093/oxfordjournals.cje.a035309

Gianella, C., \& Tompson, W. (2007). Stimulating innovation in Russia: The role of institutions and policies. OECD Papers, 7(1), 1-47. https://doi.org/10.1787/324526053041

Gokhberg, L. (2004). Russia's National Innovation System and the 'New Economy'. Problems of Economic Transition, 46(9), 8-34. https://doi.org/10.1080/10611991.2004.11049870

Golichenko, O. (2011). Modernization and reform of Russia's innovation strategy. Problems of Economic Transition, 53(9), 45-60. https;//doi.org/10.2753/PET1061-1991530903

González-Benito, Ó., Muñoz-Gallego, P.A., \& García-Zamora, E. (2015). Entrepreneurship and market orientation as determinants of innovation: The role of business size. International Journal of Innovation Management, 19(4), 1-28. https://doi.org/10.1142/S1363919615500358 
Grace-Martin, K. (2018). Why ANOVA and Linear Regression are the Same Analysis. The analysis factor. Retrieved on 15 July, 2018 from https://www.theanalysisfactor.com/why-anova-and-linear-regression-are-the-same-analysis/

Graham, L. (2013). Lonely Ideas-Can Russia Compete?. Cambridge, Massachusetts: The MIT Press.

Griliches, Z. (1990). Patent statistics as economic indicators: A survey. Journal of Economic Literature, 28(4), 1661-1707. Retrieved on 5 November, 2015 from https://EconPapers.repec.org/RePEc:aea:jeclit:v:28:y:1990:i:4:p:1661-1707

Hagen, B., Denicolai, S., \& Zucchella, A. (2014). International entrepreneurship at the crossroads between innovation and internationalization. Journal of International Entrepreneurship, 12, 111114. https://doi.org/10.1007/s10843-014-0130-8

Hidalgo, J.C. (2013). The Rise of Emerging Economies: Challenges and Liberal Perspectives. Occasional Paper 118, Liberal Institute Friedrich-Naumann-Stiftung für die Freiheit.

Hunter, M. (2012). On some of the misconceptions about entrepreneurship. Economics, Management, and Financial Markets, 7(2), 55-104. Retrieved on 5 November, 2015 from http://works.bepress.com/murray_hunter/17/

IET (2006). Rossiiskaya ekonomika v 2005 godu: Tendentsii i perspektivy. Institute for the Economy in Transition, Moscow. Retrieved on 5 November, 2015 from http://www.iet.ru/publication.php?folder-id=44\&category-id=2083

IET (2015). Rossiiskaya ekonomika v 2014 godu: Tendentsii i perspektivy. Institute for the Economy in Transition, Moscow. Retrieved on 5 November, 2015 from http://www.iet.ru/publication. php?folder-id=44\&category-id=2083

Ivančič, A., Podmenik, D., \& Hafner, A. (2014). Independent inventors, social capital, and knowledge transfer - the case of Slovenia. Innovation: The European Journal of Social Sciences, 27(3), 238253. https://doi.org/10.1080/13511610.2014.943161

Jaffe, A.B., \& Trajtenberg, M. (2002). Patents, Citations, and Innovations: A Window on the Knowledge Economy. Boston: MIT Press.

King, J.L., Gurbaxani, V., Kraemer, K.L., McFarlan, F.W., Raman, K.S., \& Yap, C.S. (1994). Institutional factors in information technology innovation. Information Systems Research, 5(2), 139-169. https://doi.org/10.1287/isre.5.2.139

Kouznetzov, A., \& Jones, A. (2009). Conditions in Russia and their effects on entry mode decisions of multinational manufacturing enterprises: A qualitative study identifying issues for further research in the area of country conditions and their impact on entry mode. Marketing Management Journal, 19(1), 84-95, https://doi.org/10.1108/17468800910991269

Kuznetsova, T., \& Roud, V. (2014). Competition, innovation, and strategy. Problems of Economic Transition, 57(2), 3-36, https://doi.org/10.2753/PET1061-1991570201

Lamoreaux, N., \& Sokoloff, K. (1996). Long-term change in the organization of inventive activity. Proceedings of the National Academy of Sciences of the United States of America, 93, 12686-12692, https://doi.org/10.1073/pnas.93.23.12686

Lu, Y.T., Eric, W.K., \& Peng, M.W. (2008). Knowledge management and innovation strategy in the Asia Pacific: Toward an institution-based view. Asia Pacific Journal of Management, 25(3), 361374, https://doi.org/10.1007/s10490-008-9100-9

Manev, I.M., \& Manolova, T.S. (2008). Entrepreneurship in transitional economies: Review and integration of nearly two decades of research (Summary). Frontiers of Entrepreneurship Research, 28(18), Article 13, https://doi.org/10.1142/S1084946710001427 
McCarthy, D.J., Puffer, S.M., Graham, L.R., \& Satinsky, D.M. (2014). Emerging innovation in emerging economies: Can institutional reforms help Russia break through its historical barriers?. Thunderbird International Business Review, 56(3), 243-260, https://doi.org/10.1002/tie.21619

Muñoz-Bullón, F. (2016). The state of innovation and entrepreneurship research. Administrative Sciences, 6(2), 1-3, https://doi.org/10.3390/admsci6020006

Narula, R., \& Dunning, J.H. (2010). Multinational enterprises, development and globalization: Some clarifications and a research agenda. Oxford Development Studies, 38(3), 263-287, https://doi.org/10.1080/13600818.2010.505684

Nelson, R. (1993). National innovation systems: A comparative analysis. Oxford: Oxford University Press.

OECD. (1997). National Innovation Systems. Retrieved on 15 November, 2015 from http://www.oecd.org/science/inno/2101733.pdf

OECD. (1999). Managing National Innovation Systems. Retrieved on 15 November, 2015 from http://echo.iat.sfu.ca/library/oecd99_managing_National_IS.pdf, 2015

OECD and SOEC. (1996). The Oslo manual: Guidelines for collecting and interpreting innovation data. Organization for Economic Co-operation and Development (OECD) and Statistical Office of the European Communities (SOEC). Paris.

Podmetina, D., Smirnova, M., Väätänen, J., \& Torkkeli, M. (2009). Innovativeness and international operations: Case of Russian R\&D companies. International Journal of Innovation Management, 13(2), 295-317, https://doi.org/10.1142/S1363919609002303

Schumpeter, J. (1947). The creative response in economic history. The Journal of Economic History, 7(2), 149-159, https://doi.org/10.1017/S0022050700054279

Segal, A. (2011). Advantage. How American Innovation Can Overcome the Asian Challenge. New York: W.W. Norton and Company.

Siemens. (2016). Siemens in Russia 2015. Retrieved on 4 January, 2017 from http://www.siemens.com/about/pool/worldwide/siemens_russia_en.pdf

Singh, J., \& Fleming, L. (2010). Lone Inventors as Sources of Breakthroughs: Myth or Reality?. Management Science, 56(1), 41-56, https://doi.org/10.1287/mnsc.1090.1072

Subbotina, T. (2007). Russia at the crossroads: Two roads to international competitiveness. Problems of Economic Transition, February, 63-87, https://doi.org/ 10.2753/PET1061-1991490803

Sweet, S.A., \& Grace-Martin, K. (2008). Data Analysis with SPSS. Boston, USA: Pearson.

Todosiichuk, A. (2011). Conditions for transition to an innovation economy. Problems of Economic Transition, 53(10), 3-25, https://doi.org/ 10.2753/PET1061-1991531001

Trade Map (2015). International Trade Centre (ITC). Retrieved on 19 December, 2015 from http://www.trademap.org/Product_SelProductCountry.aspx

Trajtenberg, M. (1999). Innovation in Israel 1968-97: A comparative analysis using patent data. NBER Working Paper Series, Working Paper 7022, National Bureau of Economic Research, https://doi.org/ 10.3386/w7022

Tseng, Ch.-Y. (2009). Technological innovation in the BRIC economies. Research Technology Management, 52(2), 29-35, https://doi.org/10.1080/08956308.2009.11657556

U.S. Congress (1995). Innovation and Commercialization of Emerging Technology. Office of Technology Assessment, OTA-BP-ITC-165, September, U.S. Government Printing Office, Washington, DC.

Veliyath, R., \& Sambharya, R.B. (2011). R\&D Investments of Multinational Corporations. Management International Review, 51(3), 407-428, https://doi.org/10.1007/s11575-011-0079-y 
Weick, C., \& Eakin, C. (2005) Independent Inventors and Innovation: An Empirical Study. The International Journal of Entrepreneurship and Innovation, 6(1), 5-15, https://doi.org/10.5367/0000000053026400

WIPO. (2014). Protecting your inventions abroad: Frequently asked questions about the patent cooperation treaty (PCT). Retrieved on 15 February, 2015 from http://www.wipo.int/pct/en/faqs/faqs.html\#note1

WIPO. (2017). The PCT now has 151 Contracting States. Retrieved on 1 February, 2017 from http://www.wipo.int/pct/en/pct_contracting_states.html

WIPO. (2015). Glossary. Retrieved on 2 April, 2015 from http://www.wipo.int/ipstats/en/statistics/glossary.html

Womp (2009). Siemens Strengthens Russia Presence, Sets Strategy for New Investment Climate, 6. Retrieved on 2 January, 2017 from http://www.womp-int.com/story/2009vol06/story030.htm

Yamakawa, Y., Peng, M., \& Deeds, D.L. (2008). What drives new ventures to internationalize from emerging to developed economies?. Entrepreneurship: Theory \& Practice, 32(1), 59-82, https://doi.org/10.1111/j.1540-6520.2007.00216.x

Zhu, Y., Wittmann, X., \& Peng, M. (2012). Institution-based barriers to innovation in SMEs in China. Asia Pacific Journal of Management, 29(4), 1131-1142, https://doi.org/10.1007/s10490-011-9263-7

\section{Author}

\section{Irina Ervits}

Irina Ervits holds a PhD in Political Science from Miami University of Ohio and is a lecturer in international business and political economy at Cologne Business School, Germany. Her research interests include innovation management, strategies of multinational enterprises and institutional development.

Correspondence to: Dr. Ervits, Cologne Business School, Hardefuststraße 1, 50677 Köln, e-mail: i.ervits@cbs.de

ORCID (1) http://orcid.org/0000-0002-4729-9498

\section{Acknowledgements and Financial Disclosure}

The author would like to thank the organisers of the 5th AIB-CEE Chapter Annual Conference 2018 for an opportunity to discuss this article, as well as the anonymous referees for their insightful comments.

\section{Copyright and License}

This article is published under the terms of the Creative Commons

Attribution - NoDerivs (CC BY-ND 4.0) License

http://creativecommons.org/licenses/by-nd/4.0/

Published by the Centre for Strategic and International Entrepreneurship - Krakow, Poland 